\title{
Effect of Chronic Malnutrition on Intestinal Structure, Epithelial Renewal, and Enzymes in Suckling Rats
}

\author{
ERNESTO GUIRALDES AND J. RICHARD HAMILTON ${ }^{(40)}$ \\ Division of Gastroenterology, Department of Paediatrics, University of Toronto, and Research Institute, The Hospital \\ for Sick Children, Toronto, Ontario, Canada M5G 1 X8
}

\section{Summary}

To evaluate the impact of malnutrition on the developing gut, we studied small bowel structure, epithelial renewal, and enzymes in suckling rats deprived of adequate nutrient from birth. Rat pups were suckled by foster dams fed ad libitum one of three isocaloric, semipurified diets containing 6,9, or 25\% (control) protein throughout gestation and lactation. An additional control group consisted of pups raised with their natural, chow-fed mothers. Although survival of the pups, $98 \%$ in the chow-fed and $25 \%$ protein groups, decreased to $83 \%$ in the $9 \%$ groups and $53 \%$ in the $6 \%$ protein groups, body and gut weights were remarkably uniform within each study group. Mean body weight, gut weight, villus height, and crypt depth were markedly and significantly less in the 6 and 9\% pups when compared with those in the chow and $25 \%$ control groups, the $6 \%$ group being significantly more affected was than the $9 \%$ group $(P<0.001)$. Pups raised by chow-fed mothers also weighed significantly less $(P<0.001)$ than did those raised by dams fed the $25 \%$ protein diet. Total small intestinal protein and DNA content of mucosal scrapings were less in 6 than 9\% rat pups $(P<0.001)$, which in turn were less than those in the $25 \%$ group $(P<0.05)$. The protein/DNA ratio in the small intestine of the 6\% animals only was reduced when compared with the $25 \%$ group $(P$ $<0.05$ ). Epithelial cell migration assessed by autoradiography with $\left[{ }^{3} \mathbf{H}\right]$ thymidine was significantly slower in both proximal and distal intestinal segments of the $6 \%$ animals when compared with those from the $25 \%$ group $(P<0.001)$. Incorporation of the ${ }^{3} \mathrm{H}$, seen by autoradiography after $1 \mathrm{hr}$, was also signficantly decreased in the 6\% group $(P<0.001)$. Calculated for the total small intestine, lactase, sucrase, alkaline phosphatase, and thymidine kinase activities were significantly diminished $(P \leq 0.001)$ in the $6 \%$ animals compared with $25 \%$ controls. Calculated in relation to mucosal protein content and compared with $25 \%$ controls, sucrase and alkaline phosphatase activities were significantly decreased $(P<0.001)$ in both proximal and distal small intestinal segments of the $6 \%$ animals, but thymidine kinase activity was decreased only in the distal segment $(P<0.001)$. However, lactase specific activity was increased in both proximal and distal segments from the $6 \%$ group $(P<0.001)$. Further studies of this phenomenon demonstrated a significant increase in intracellular acid $\beta$-galactosidase $(P<0.001)$, particularly in the distal intestinal segment, but also a marked increase in brush border $\beta$-galactosidase.

Our data demonstrate that in the small intestinal mucosa of the suckling rat, chronic malnutrition causes a decreased number of cells and impaired epithelial proliferation. These abnormalities reflect a profound direct impact of malnutrition on the gut of the young animal and demonstrate a delay in the normal pattern of postnatal maturation of the small intestinal epithelium.

In most mammalian species, the small intestinal epithelium undergoes significant development in early postnatal life $(10,11$, 17). To evaluate the impact of protein-calorie malnutrition on the developing gut, we studied rats deprived of adequate nutrients from birth. This paper reports the effects of reduced maternal dietary protein on small bowel structure, epithelial renewal, and enzymes in suckling animals. Our findings suggest that chronic undernutrition influences not only structure and function, but also maturational patterns in the small intestine during early life.

\section{MATERIALS AND METHODS}

The technique described by Nakamoto and Miller (25) was used to produce malnutrition in suckling rats. Pregnant females of the Wistar strain, obtained on the second or third day of gestation, were assigned at random within 2 days to one of four dietary groups. They were fed ad libitum either standard rat chow (33) or one of three isocaloric semipurified diets containing 25 (control), 9 , or $6 \%$ casein (34) as the sole source of protein (Table 1) throughout pregnancy and lactation. The three groups receiving semipurified diets were designated to serve as foster mothers. Normal newborn litters each consisting of eight pups taken from normal chow-fed dams 24 to $48 \mathrm{hr}$ after birth were transferred to these foster mothers, who themselves had given birth to litters within the previous $48 \mathrm{hr}$. An additional control group consisted of normal litters left with their own chow-fed mothers throughout lactation. A preliminary study, under identical conditions, had shown no significant difference between normal pups suckling on their natural mother and those on a normal chow-fed foster mother. The rat pups were killed by decapitation at 18 to 20 days of life when all were still suckling and did not have access to other sources of food.

For autoradiographic study, animals were injected intraperitoneally with $\left[{ }^{3} \mathrm{H}\right]$ thymidine $(35)(46.8 \mathrm{Ci} /$ mmole, $1 \mu \mathrm{Ci} / \mathrm{g}$ body weight) 23 or 41 hours before death. Specimens of midproximal and middistal small bowel were quickly removed and processed by histologic and autoradiographic methods described previously $(6,22)$. Full-thickness intestine was fixed in Bouin's solution, sectioned, processed for autoradiography, and stained with hemotoxylin and eosin for light microscopy. A calibrated eyepiece was used to assess 10 to 15 crypt-villus units visible from crypt base to villus tip. To derive a labeling index, 50 crypts were scanned in each specimen; a cell was considered labeled when at least five grains were seen over the nucleus (1). Enterocyte migration rate was calculated by measuring the distance between crypt base and the foremost labeled cell at 23 or at $41 \mathrm{hr}$ in 20 well-oriented crypt-villus units.

For biochemical studies, the small intestine was removed gently, flushed with ice-cold isotonic saline, and divided into equal proximal and distal halves. Contents of the stomach and large intestine were emptied, and these organs were weighed together with the small intestine. For measurements of protein (21) and DNA (30) content and enzymatic activities, full-thickness mucosa, obtained from each small intestinal segment by scraping with a glass slide, was homogenized in $2.5 \mathrm{mM}$ EDTA $(100 \mathrm{mg} / \mathrm{ml})$. Sucrase and total lactase activities were measured by Dahlqvist's method (3), alkaline phosphatase by the method of Kelly and Hamilton (14), 
Table 1. Composition of the synthetic diets (34) ( $\mathrm{g} / \mathrm{kg}$ dry weight)

\begin{tabular}{lccc}
\hline & \multicolumn{3}{c}{ Diet } \\
\cline { 2 - 4 } & $6 \%$ protein & $9 \%$ protein & $25 \%$ protein \\
\hline Casein & 60 & 90 & 250 \\
Sucrose & 163 & 163 & 163 \\
Dextrin & 352 & 322 & 162 \\
Dextrose & 163 & 163 & 163 \\
Corn oil & 143 & 143 & 143 \\
Mineral mixture & 40 & 40 & 40 \\
Vitamin mixture & 40 & 40 & 40 \\
Choline chloride $(50 \% \mathrm{w} / \mathrm{vl})$ & $4 \mathrm{ml}$ & $4 \mathrm{ml}$ & $4 \mathrm{ml}$ \\
Methionine & 1 & 1 & 0 \\
Agar & 40 & 40 & 40 \\
Distilled water & $1000 \mathrm{ml}$ & $1000 \mathrm{ml}$ & $1000 \mathrm{ml}$ \\
\hline
\end{tabular}

and thymidine kinase by a modification (15) of the method of Klemperer and Haynes (16). The techniques of Koldovsky et al. (18) were used to measure the specific brush border and soluble $\beta$-galactosidases.

After enzyme data from the 6 and $25 \%$ protein groups had been analyzed, an additional group was added to the study. Two litters were studied at 8 days of age when their mean body weight, 14.9 $\pm 0.5 \mathrm{~g}$ (mean \pm S.E.), was the same as that of the 20 -day-old malnourished $6 \%$ protein group $(13.6 \pm 3.1 \mathrm{~g})$.

Groups were compared using Student's $t$ test. Enzyme data were analyzed as logs and tabulated as antilogs.

\section{RESULTS}

Mean weight gain of the dams receiving the $6 \%$ diet $(0.2 \pm 0.1$ $\mathrm{g} /$ day; mean \pm S.E. $)$, was negligible and significantly less $(P<$ $0.001)$ than that for the groups fed $25 \%$ protein $(6.8 \pm 0.6)$, chow $(5.9 \pm 0.3)$, or $9 \%$ protein $(5.1 \pm 0.7)$ diets. Survival of the pups, $98 \%$ in the chow-fed and $25 \%$ protein groups, decreased to $83 \%$ in the $9 \%$ protein group and $53 \%$ in the $6 \%$ protein group. Body and gut weights of the pups were remarkably uniform within the study groups (Fig. 1) despite this variability in final litter size of the malnourished rats. Mean body weight of the 18- to 20-day-old pups in the $6 \%$ protein group $(13.6 \pm 3.1 \mathrm{~g})$ was significantly less $(P<0.001)$ than that of the $9 \%$ protein group $(25.6 \pm 4.2 \mathrm{~g})$ the chow-fed group $(35.5 \pm 6.3 \mathrm{~g})$ and the $25 \%$ protein group (51.7 $\pm 7.9 \mathrm{~g})$. The $9 \%$ protein pups weighed significantly less than either the chow or $25 \%$ protein pups $(P<0.001)$, and the chowfed pups weighed less than did the $25 \%$ protein group $(P<0.001)$.

The pattern of mean gut weights was similar to that seen for body weights. In the $6 \%$ protein group, mean gut weight $(0.9 \pm$ $0.5 \mathrm{~g})$ was less $(P<0.001)$ than that of the $9 \%$ protein group $(1.3$ $\pm 0.5 \mathrm{~g})$, the chow-fed group $(2.3 \pm 0.6 \mathrm{~g})$ and the $25 \%$ protein group $(4.2 \pm 0.5 \mathrm{~g})$. Mean villus height and crypt depth, measured by light microscopy in proximal and distal small intestine, were significantly less in the $6 \%$ protein group compared with the other three study groups $(P<0.001)$ (Table 2$)$. In the $9 \%$ protein group, these same measurements were less than those in the chow and $25 \%$ protein groups $(P<0.001)$, and in the chow, they were less than the $25 \%$ protein group $(P<0.001)$.

Total small intestinal protein and DNA content of mucosal scrapings (Fig. 2) followed a similar pattern. The amounts of protein and DNA were less in the 6\% protein group than in the $9 \%$ protein group $(P<0.001)$, which in turn were less than the $25 \%$ protein group $(P<0.05)$. No differences were observed between the chow-fed and $25 \%$ protein groups. The protein/DNA ratio was similar in all study groups except the $6 \%$ protein pups in which the ratio was reduced compared with the $25 \%$ protein group $(P<0.05)$.

Autoradiographic studies of small intestinal epithelial renewal, done only on the 6 and 25\% protein groups, showed a marked decrease of label incorporation into crypt enterocytes at $1 \mathrm{hr}$ and a slower progression of labeled enterocytes along the crypt-villus unit at 23 and $41 \mathrm{hr}(P<0.001)$ (Table 2$)$. Consequently mean cell migration rates, calculated from the autoradiographic data, revealed a slower rate in the nutritionally deprived groups compared with controls.

Calculated for the total small intestine, lactase, sucrase, alkaline phosphatase, and thymidine kinase activities each decreased markedly in the $6 \%$ protein animals compared with $25 \%$ protein controls $(P<0.001)$ (Table 3$)$. When mucosal enzyme activities were calculated in relation to protein content to estimate specific activity, some interesting patterns emerged (Table 4). In proximal intestinal segments from the $6 \%$ protein group, mean specific activities of sucrase and alkaline phosphatase were less than those of $25 \%$ protein animals $(P<0.001)$, but thymidine kinase activities did not differ between groups. In the distal small intestinal segments, sucrase, alkaline phosphatase, and thymidine kinase activities all were diminished $(P<0.001)$ in the $6 \%$ protein group. However, lactase specific activity data revealed a pattern that differed markedly from the other mucosal enzymes studied (Table 4). Measured by a conventional technique at neutral $\mathrm{pH}$, lactase specific activity was markedly greater $(P<0.001)$ in the $6 \%$ protein group than in controls; the difference between the groups was particularly wide in the distal segments. A large portion of this difference could be attributed to the high level of soluble intracellular acid $\beta$-galactosidase activity in tissue from the $6 \%$ protein group (Table 4 ), but the specific activity of the brush border enzyme measured in the presence of an inhibitor (18) also rose to account for the vast differences in total specific activity (18).

In 8 -day-old pups suckled by dams receiving the $25 \%$ protein diet, almost no sucrase specific activity was detected in proximal segments, $(0.2 \pm 0.2 \mathrm{u} / \mathrm{g}$ protein $)$ or in distal segments $(0.4 \pm 0.6$ $\mathrm{u} / \mathrm{g}$ protein). These data did not differ significantly from those in the 20 -day-old malnourished $6 \%$ protein group. Lactase activity $(74.4 \pm 9.4 \mathrm{u} / \mathrm{g}$ protein in the proximal segment, $104.3 \pm 19.9 \mathrm{u} /$ $\mathrm{g}$ in the distal), and acid $\beta$-galactosidase activity $(4.6 \pm 1.1 \mathrm{u} / \mathrm{g}$
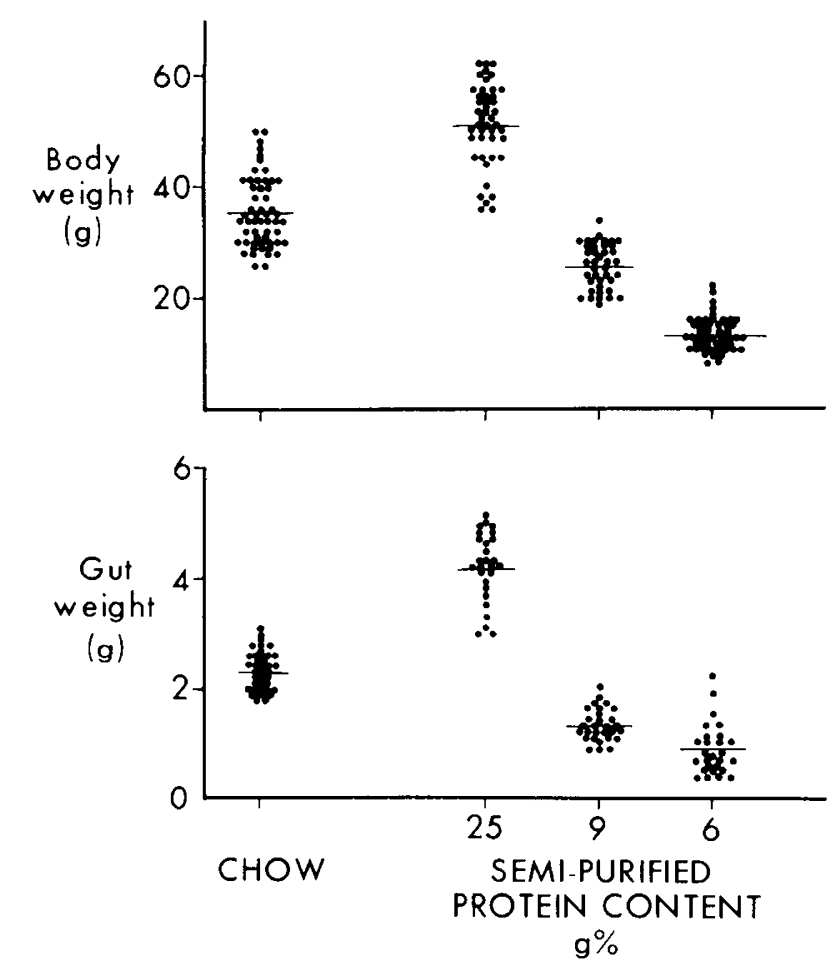

Maternal Diet

Fig. 1. Body and gut weights of 18- to 20-day-old rat pups raised by foster mothers fed either standard chow or a semipurified diet containing 25,9 , or $6 \%$ protein. Each point represents one animal. Mean values are represented by horizontal lines. The weights decrease progressively as maternal dietary protein is decreased. 
Table 2. Light microscopy and autoradiography studies in the small intestines of 18-to 20-day-old rats

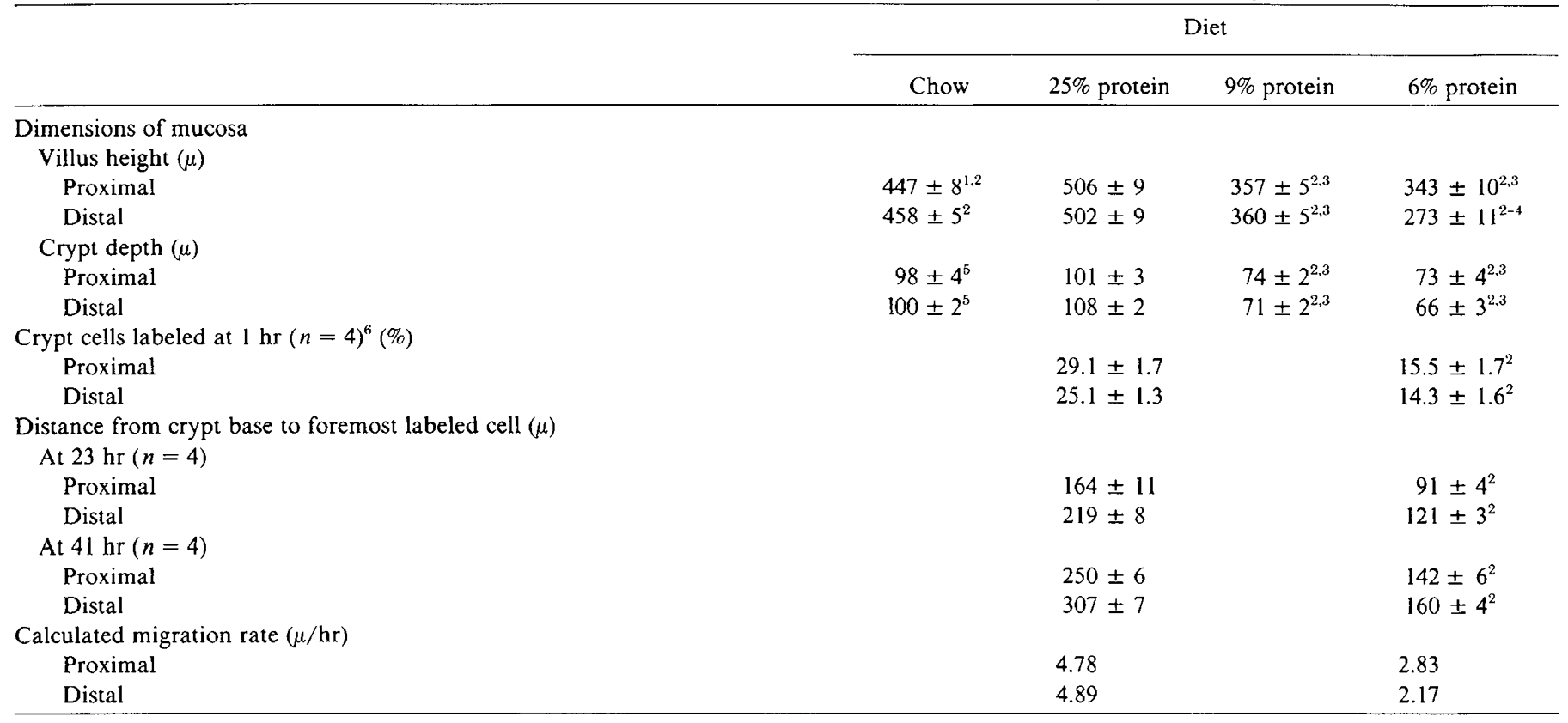

${ }^{1}$ Mean \pm S.E.

${ }^{2}$ Significantly different from corresponding mean value in the $25 \%$ protein group $(P<0.001)$.

${ }^{3}$ Significantly different from corresponding mean value in the chow-fed group $(P<0.001)$.

${ }^{4}$ Significantly different from corresponding mean value in the $9 \%$ protein group $(P<0.001)$.

${ }^{5}$ Significantly different from corresponding mean value in the $25 \%$ protein group $(P<0.01)$.

${ }^{6} n$, number of animals in each study.

\section{$(M \pm S E)$}
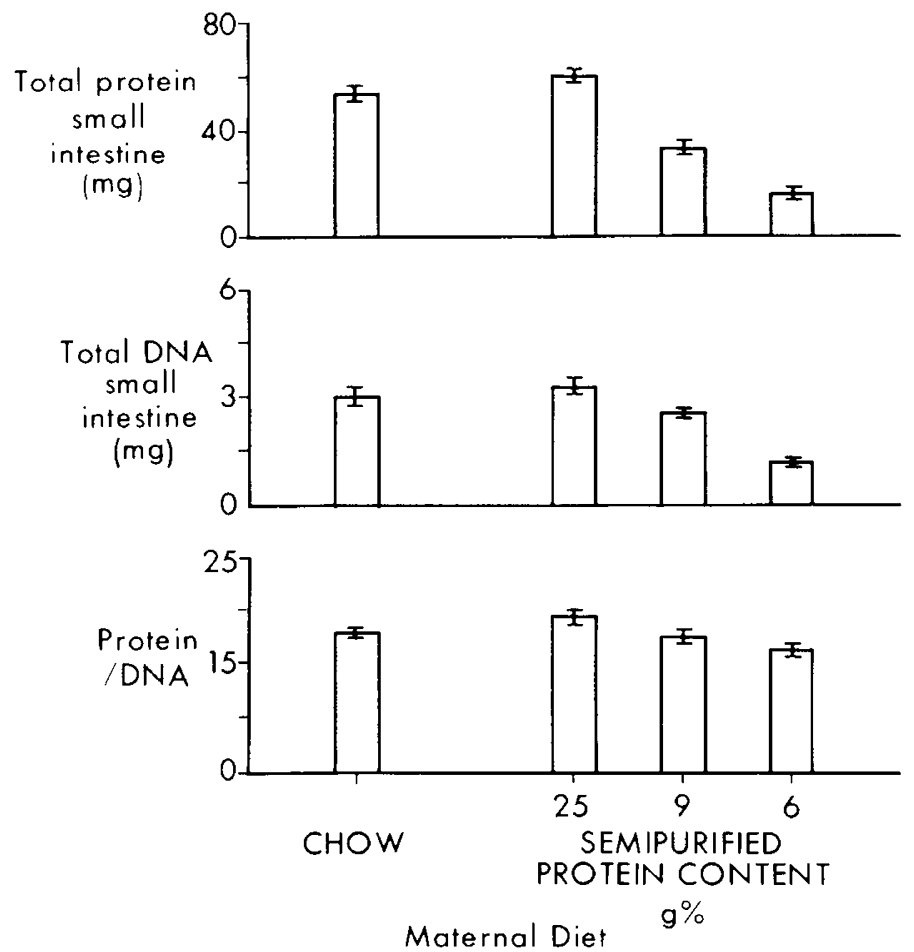

Fig. 2. Total protein and DNA contents of the small intestine of the 18- to 20-day-old rat pups showing progressive decrease with decreased maternal dietary protein. The protein/DNA ratio is significantly diminished only in the $6 \%$ group (mean \pm S.E.).

protein in the proximal segment and $58.3 \pm 3.8 \mathrm{u} / \mathrm{g}$ protein in the distal segment were higher than comparable values in 20-day old control $(25 \%)$ pups $(P<0.001)$. In general, these findings did not differ from those found in 20 -day-old malnourished $6 \%$ protein pups except that in the distal segment, acid $\beta$-galactosidase specific activity was even higher in the 20 -day-old malnourished group than in the 8-day-old control group $(P<0.001)$.

\section{DISCUSSION}

Clearly, the technique of Nakamoto and Miller (25) was effective in producing severe malnutrition in the suckling rat. Dietary protein deprivation may cause minor differences in the quality of rat milk, but the severe malnutrition seen in our suckling pups can be attributed largely to a reduced quantity of rat milk $(2,23)$. A progressive decrease in protein from 25 to 9 to $6 \%$ in the maternal diet was reflected in an increasingly severe effect on suckling litters, their survival, their body weight, their gut weight, and the protein content of their intestines. Pups in the 25\% protein control group were bigger and had heavier intestines than did the controls suckled by their own mothers and fed a standard chow containing $23.4 \%$ protein (33). A nutritional advantage of fostering was ruled out by our preliminary study. Either conventional rat chow provides a suboptimal diet during pregnancy and lactation or the intake of semipurified agar diet was excessive. The latter explanation seems likely and might be attributable to the appeal to the rat's "sweet tooth" of the sucrose containing semipurified $\operatorname{diet}(27)$.

Table 3. Enzyme activities for total small intestine in 18- to 20day-old rats

\begin{tabular}{lcc}
\hline & \multicolumn{2}{c}{ Dietary group $^{1}$} \\
\cline { 2 - 3 } Total enzyme activity (units) & $\begin{array}{c}25 \% \text { protein } \\
(n=25)\end{array}$ & $\begin{array}{c}6 \% \text { protein } \\
(n=24)\end{array}$ \\
\hline Lactase & $34.0 \pm 0.4^{2}$ & $17.7 \pm 0.1$ \\
Sucrase & $0.6 \pm 0.04$ & $0.01 \pm 0.001$ \\
Alkaline phosphatase & $771 \pm 40$ & $90 \quad \pm 21$ \\
Thymidine kinase & $265 \pm 25$ & $31 \quad \pm 2$ \\
\hline
\end{tabular}

${ }^{1}$ All differences between dietary groups were significant $(P<0.001)$

${ }^{2}$ Mean \pm S.E. 
Table 4. Activities of small intestinal mucosal enzymes in 18- to 20-day-old rats

\begin{tabular}{|c|c|c|}
\hline \multirow[b]{2}{*}{ Enzyme } & \multicolumn{2}{|c|}{ Diet } \\
\hline & $\begin{array}{l}25 \% \text { casein } \\
(n=25)\end{array}$ & $\begin{array}{l}6 \% \text { casein } \\
(n=24)\end{array}$ \\
\hline \multicolumn{3}{|l|}{ Lactase (units/g protein) } \\
\hline Proximal & $51.2 \pm 4.8^{1}$ & $89.9 \pm 6.5$ \\
\hline Distal & $66.1 \pm 3.6$ & $134.4 \pm 6.7$ \\
\hline \multicolumn{3}{|c|}{$\beta$-galactosidases (units/g protein) } \\
\hline \multicolumn{3}{|c|}{ Neutral-brush border } \\
\hline Proximal & $44.0 \pm 2.4$ & $84.4 \pm 9.7$ \\
\hline Distal & $45.3 \pm 2.8$ & $79.3 \pm 4.8$ \\
\hline \multicolumn{3}{|l|}{ Acid-soluble } \\
\hline Proximal & $2.1 \pm 0.2$ & $7.6 \pm 1.1$ \\
\hline Distal & $15.0 \pm 2.7$ & $92.5 \pm 7.6$ \\
\hline \multicolumn{3}{|l|}{ Sucrase (units/g protein) } \\
\hline Proximal & $8.6 \pm 1.6$ & $0.8 \pm 0.2$ \\
\hline Distal & $10.7 \pm 2.0$ & $0.2 \pm 0.3$ \\
\hline \multicolumn{3}{|c|}{$\begin{array}{l}\text { Alkaline phosphatase (units/mg pro- } \\
\text { tein) }\end{array}$} \\
\hline Proximal & $13.0 \pm 0.8$ & $6.2 \pm 0.7$ \\
\hline Distal & $16.0 \pm 0.9$ & $7.0 \pm 0.5$ \\
\hline \multicolumn{3}{|c|}{ Thymidine kinase (units/mg protein) } \\
\hline Proximal $^{2}$ & $4.4 \pm 0.2$ & $3.2 \pm 0.4$ \\
\hline Distal & $3.6 \pm 0.4$ & $1.5 \pm 0.2$ \\
\hline
\end{tabular}

${ }^{1}$ Mean \pm S.E.

${ }^{2}$ All differences between dietary groups were significant $(P<0.001)$ except for thymidine kinase in the proximal segment (not significant).

The protein and DNA content of the intestine and total activities of a variety of small intestinal mucosal enzymes decreased in the pups as maternal dietary protein was diminished. The more severe the dietary deprivation, the more marked was its apparent impact on the gut. Our findings are in keeping with the general and profound reduction in the number of cells, including epithelial cells in the mucosa (12). In adult rats, Hopper et al. (13) noted decreasing numbers of crypt cells after short-term starvation but no decline in the absolute numbers of dividing cells until a proteinfree diet was given for $11 \mathrm{wk}$.

Because pups fostered on mothers receiving a $6 \%$ protein diet had a consistent pattern of structural and enzymatic abnormalities, this group was subjected to more detailed study and compared with the well-nourished $25 \%$ protein controls. Mortality was highest in this $6 \%$ protein group, causing variability in litter size, but body and gut weights were remarkably uniform. Only in this same group was the protein/DNA ratio significantly reduced, suggesting a reduction in mean cell size (5) in addition to the decreased cell numbers described above. Our microscopic and autoradiographic studies are in keeping with these findings and point to a profound defect in the proliferation of enterocytes in the mucosal crypts of the small intestine. In the $6 \%$ protein group, villus and crypt dimensions were reduced, injected thymidine was incorporated into the nuclei of small intestinal crypt enterocytes less actively, and the migration rate of those enterocytes along the villi was reduced.

To some extent, the mucosal enzyme data from the present study reflect the decrease in intestinal mass and mucosal proliferative activity in the malnourished animals. Not only was there a reduction of the total intestinal activity for all enzymes studied, but the specific activities of alkaline phosphatase and sucrase, enzymes normally synthesized as the enterocyte migrates from crypt along the villus, were diminished in both proximal and distal segments. The specific activity of thymidine kinase, an enzyme normally associated with cell division in the crypts, also was significantly diminished in the distal segment of the malnourished rat pups. Because sucrase (29) and alkaline phosphatase $(7,22)$ activities normally increased sharply in the rat small intestine at the time of weaning, these findings do suggest the possibility that chronic malnutrition delays postnatal maturation of the small bowel. In this regard, our data on mucosal lactase activity are of particular interest because in the malnourished rats specific activity of lactase was approximately twice that of controls. Lactase activity has been found preserved or increased in adult rats subjected to fasting, to semistarvation, or to protein deprivation $(24,31,32)$, in protein-deprived weanling rats $(28)$, and in malnourished suckling rats $(8,26)$. In theory, high lactase activity could be caused in the present study either by a relatively low rate of degradation or by a high rate of synthesis of the mucosal $\beta$ galactosidases. Our findings suggest a general suppression of protein synthesis. Impaired exocrine pancreatic function, known to accompany chronic malnutrition in suckling rats (9), might also have contributed by reducing the degradation of brush border enzymes. However, in the present study, lactase activity alone was high whereas the other brush border enzymes, sucrase and alkaline phosphatase, presumably equally susceptible to pancreatic proteases, were diminished.

Clearly, severe chronic malnutirtion has a particularly severe impact on the young animal and its small intestine. The present studies were carried out in suckling rats at an age when normally a complex series of maturational events is occurring in the small intestine. Our data suggest that at this early age malnutrition, over and above any direct impact on intestinal cells, caused a delay in postnatal maturation of the small intestinal epithelium. A similar hypothesis has recently been advanced by Hatch et al. (8), who found in a different model of malnutrition a pattern of increased total lactase and decreased sucrase activity in the small intestinal mucosa of the suckling rat. Our data show, not only a decrease in the enzymes that normally increase sharply at weaning, sucrase (29) and alkaline phosphatase $(7,22)$, but also high activity of the $\beta$-galactosidases, enzymes that normally diminish at the same age $(4,29)$. The high levels of soluble acid $\beta$-galactosidase, particularly in the distal segment of the small intestine seen in our 8-day-old controls, were also observed by Koldovsky and Chytil (19) and Koldovsky and Sunshine (20) in normal 8- to 16-day-old rats.

\section{REFERENCES AND NOTES}

1. Aldewachi, H. S., Wright, N. A., Appleton, D. R., and Watson, A. J.: The effect of starvation and refeeding on cell population kinetics in the rat small bowel mucosa. J. Anat., 119: 105 (1975).

2. Crnic, L. S., and Chase, H. P.: Models of infantile undernutrition in rats: effects on milk. J. Nutr., I08: 1755 (1978).

3. Dahlquist, A.: Assay of intestinal disaccharidases. Anal. Biochem., 22: 99 (1968).

4. Doell, R. G., and Kretchmer, N.: Studies of the small intestine during development. I. Distribution and activity of $\beta$-galactosidase. Biochim. Biophys. Acta, 62: 353 (1962)

5. Enesco, M., and Leblond, C. P.: Increase in cell number as a factor in the growth of the organs and tissues of the young male rat. J. Embryol. Exp. Morphol., 10: 530 (1962).

6. Gall, D. G., Chapman, D., Kelly, M., and Hamilton, J. R.: $\mathrm{Na}^{+}$transport in jejunal crypt cells. Gastroenterology, 72: 452 (1977).

7. Halliday, R.: The effect of steroid hormones on the absorption of antibody by the young rat. J. Endocrinol., 18: 56 (1959).

8. Hatch, T. F., Lebenthal, E., Branski, D., and Krasner, J.: The effect of early postnatal acquired malnutrition on intestinal growth, disaccharidases and enterokinase. J. Nutr., 109: 1874 (1979).

9. Hatch, T. F., Lebenthal, E., Krasner, J., and Branski, D.: Effect of postnatal malnutrition on pancreatic zymogen enzymes in the rat. Am. J. Clin. Nutr., 32: 1224 (1979).

10. Henning, S. J., and Kretchmer, N.: Development of intestinal function in mammals. Enzyme (Basel), 15: 3 (1973).

11. Herbst, J. J., and Sunshine, P.: Postnatal development of the small intestine of the rat. Pediatr. Res., 3: 27 (1969).

12. Hooper, C. S., and Blair, M.: The effect of starvation on epithelial renewal in the rat duodenum. Exp. Cell Res., 14: 175 (1958).

13. Hopper, A. F., Wannemacher, R. W., Jr., and McGovern, P. A.: Cell population changes in the intestinal epithelium of the rat following starvation and protein depletion. Proc. Soc. Exp. Biol. Med., 128: 695 (1968)

14. Kelly, M. H., and Hamilton, J. R.: A micro-technique for the assay of intestinal alkaline phosphatase. Results in normal children and in children with celiac disease. Clin. Biochem., 3: 33 (1970).

15. Kerzner, B., Kelly, M. H., Gall, D. G., Butler, D. G., and Hamilton, J. R.: Transmissible gastroenteritis: sodium transport and the intestinal epithelium 
during the course of viral enteritis. Gastroenterology, 72: 457 (1977).

16. Klemperer, H. G., and Haynes, G. R.: Thymidine kinase in rat liver during development. Biochem. J., 108: 541 (1968).

17. Koldovsky, O.: Development of the Functions of the Small Intestine in Marmmals and Man. (S. Karger, Basel, 1969).

18. Koldovsky, O., Asp, N. G., and Dahlqvist, A.: A method for the separate assay of "neutral" and "acid" $\beta$-galactosidase in homogenates of rat small-intestinal mucosa. Anal. Biochem., 27: 409 (1969).

19. Koldovsky, O., and Chytil, F.: Postnatal development of $\beta$-galactosidase activity in the small intestine of the rat. Effect of adrenalectomy and diet. Biochem. $J$., 94: 226 (1965).

20. Koldovsky, O., and Sunshine, P.: Effect of cortisone on the developmental pattern of the neutral and the acid $\beta$-galactosidase of the small intestine of the rat. Biochem. J., 117: 467 (1970).

21. Lowry, O. H., Rosebrough, N. J., Farr, A. L., and Randall, R. J.: Protein measurement with the Folin phenol reagent. J. Biol. Chem., 193: 265 (1951).

22. McNeill, L. K., and Hamilton, J. R.: The effect of fasting on disaccharidase activity in the rat small intestine. Pediatrics, 47: 65 (1971).

23. Moog, F., and Yeh, K. -Y.: Intestinal alkaline phosphatase of the rat: development and distribution of activity with phenylphosphate and $\beta$-glycerophosphate. Comp. Biochem. Physiol., 44B: 657 (1973).

24. Muller, A. J., and Cox, W. M., Jr.: The effect of changes in diet on the volume and composition of rat milk. J. Nutr., 31: 249 (1946).

25. Nakamoto, T., and Miller, S. A.: Effect of protein-energy malnutrition on the growth of mandible and long bone in newborn male and female rats. J. Nutr., 107: 983 (1977).

26. Nathan, L. R. J., and Younoszai, M. K.: Intestinal disaccharidase activity in growth retarded (GR) infant rats. Gastroenterology (Abstract), 76: 1208 (1979).

27. National Research Council. Subcommittee on Laboratory Animal Nutrition Nutrient Requirements of Laboratory Animals: Cat, Guinea Pig, Hamster, Monkey, Mouse, Rat, Ed. 2. p. 67 (National Academy of Sciences, Washington, D. C., 1972).

28. Prosper, J., Murray, R. L., and Kern, F., Jr.: Protein starvation and the small intestine. II. Disaccharidase activities. Gastroenterology, 55: 223 (1968).

29. Rubino, A., Zimbalatti, F., and Auricchio, S.: Intestinal disaccharidase activity in adult and suckling rats. Biochim. Biophys. Acta, 92: 305 (1964).

30. Schmid, P., Schmid, C., and Brodie, D. C.: The determination of the total deoxyribose of deoxyribonucleic acid. J. Biol. Chem., 238: 1068 (1963).

31. Solimano, G., Burgess, E. A., and Levin, B.: Protein-calorie malnutrition: effect of deficient diets on enzyme levels of jejunal mucosa of rats. Br. J. Nutr., 21: 55 (1967).

32. Troglia, O. M., Laughrey, E. G., and Henley, K. S.: Effect of quantitative undernutrition on the activities of intestinal disaccharidases in the rat. Gastroenterology, 58: 669 (1970).

33. Purina Lab Chow (23.4\% protein), Ralston Purina Co., St. Louis, MO.

34. U. S. Biochemical Corporation, Cleveland, $\mathrm{OH}$.

35. New England Nuclear Canada, Lachine, P.Q., Canada.

36. This paper was presented in part at the Annual Scientific Meeting of the American Pediatric Society, San Antonio, Texas, 1980.

37. During the course of these studies, Dr. Guiraldes was supported by the Anna Bradbury Springer Fellowship, University of Toronto, and a fellowship from Smith, Kline and French Limited.

38. The present address of Dr. Guiraldes is: Department of Pediatrics, Faculty of Medicine East, University of Chile, Hospital L. Calvo Mackenna, Santiago 9, Chile.

39. The authors are grateful to Dr. Sandford Miller, Dr. James Fox, and Angela Chen, Massachusetts Institute of Technology, and Dr. Grant Gall, University of Calgary, for their assistance and stimulating suggestions. We also thank Mary Perdue, Angela Chan, Piya Drew, Barbara Jones, Mahmood Khan, Bill Wilson, and the staff of the Animal Facility, The Hospital for Sick Children, for expert technical assistance.

40. Requests for reprints should be addressed to: J. R. Hamilton, M.D., Division of Gastroenterology, The Hospital for Sick Children, 555 University Avenue, Toronto, Ontario Canada M5G IX8.

41. Received for publication July $25,1980$.

42. Accepted for publication November 12, 1980. 